\title{
Unregulated use of TBT-based antifouling paints in Israel (eastern Mediterranean): high contamination and imposex levels in two species of marine gastropods
}

\author{
Gil Rilov ${ }^{1}$, Avital Gasith ${ }^{1}$, Stewart M. Evans ${ }^{3}$, Yehuda Benayahu ${ }^{2, *}$ \\ ${ }^{1}$ Institute for Nature Conservation Research, ${ }^{2}$ Department of Zoology, George S. Wise Faculty of Life Sciences, \\ Tel Aviv University, Ramat-Aviv, Tel Aviv 69978, Israel \\ ${ }^{3}$ Dove Marine Laboratory, Cullercoats, Tyne \& Wear NE30 4PZ, United Kingdom
}

\begin{abstract}
The use of tributyltin (TBT)-based antifouling paints is unregulated in Israel, and levels of contamination are high along the Mediterranean coastline there. This is indicated by concentrations of butyltins found in the tissue, and by imposex in the whelks Stramonita haemastoma and Hexaplex trunculus. Both the old (since 1974) and new (since late 1995) marinas we studied are hotspots of pollution. Imposex indices were very high at the old marina (RPSI $>100$, VDSI 4 to 5); all female $H$. trunculus and some $S$. haemastoma were sterile within a distance of ca $1 \mathrm{~km}$ from it. The new marina offered a unique opportunity to witness the rapid and intense response of the whelks to TBT pollution in an open coastline. Despite a marked decrease in levels of contamination at distances of 1 to $2 \mathrm{~km}$ from both marinas, there were nevertheless detectable levels of butyltins sufficient to cause imposex in reference sites far from high shipping activity. There is evidence that TBT contamination affects abundance and relative growth rates, of male and female, of the 2 whelks around the marinas. Differences in biological response to TBT were observed between the 2 whelk species: $S$. haemastoma had higher levels of organotins than $H$. trunculus in most study sites, which may be related to different sensitivity or accumulation rates. In S. haemastoma a male-biased sex ratio was revealed around the old Tel Aviv marina, which may be derived from either female mortality or from a complete sex change in some females. Further development of marinas at coastal resorts is undesirable, certainly in the absence of regulations limiting the use of TBT-based antifoulants, and the establishment of such regulations is highly recommended.
\end{abstract}

KEY WORDS: Mediterranean Sea $\cdot$ Israel $\cdot$ TBT $\cdot$ Imposex $\cdot$ Stramonita haemastoma Hexaplex trunculus

\section{INTRODUCTION}

Tributyltin (TBT) has been used successfully as an effective biocide in antifouling paints for more than 2 decades. It has been described as the most toxic substance ever deliberately introduced into the aquatic environment (Goldberg 1986), causing damage by leaching from the antifoulants used on boat hulls and mariculture cages into the water column. The best-

\footnotetext{
-Corresponding author. E-mail: denlit@post.tau.ac.il
}

documented cases of its impact on non-target organisms are those concerning the Pacific oyster Crassostrea gigas and the dogwhelk Nucella lapillus. TBT was responsible for malformation of oysters' shells, poor spatfall and the near collapse of oyster farming in western France in the early 1980s (Claisse \& Alzieu 1993). It also led to a decline in populations of $N$. lapillus in southwest England (Bryan et al. 1986). N. lapillus females developed the condition known as imposex, in which male characteristics, including a penis and vas deferens, become superimposed on their own genitalia. Many of the populations which were surveyed in 
the 1980 s suffered from high female mortality and reproductive failure. The worst-affected ones were dominated by old males, and the species became locally extinct in some places (Bryan et al. 1986, Evans et al. 1996). Subsequently, it became evident that imposex was widespread and described in at least 72 species of gastropods world-wide (Oehlmann et al. 1991). TBT was also demonstrated to have lethal and sub-lethal effects on many other marine taxa (see for review Alzieu 1996).

TBT can be effective at concentrations close to the limits of chemical detection and, consequently, biological responses to it have been developed as indicators, including abnormal shell growth in oysters (Dyryanda 1992) and imposex in gastropods (see above). Gibbs et al. (1987) recommended the use of 2 quantitative measures of imposex in Nucella lapillus: (1) relative penis size index (RPSI), which compares the size of the female penis with that of the male as a standard; and (2) vas deferens sequence index (VDSI), which recognises 6 stages, primarily in the development of the vas deferens and penis. Females at VDSI Stages 1 to 4 are still capable of breeding, but at Stages 5 and 6 their vas deferens occludes the opening of the genital pore, rendering them sterile. These responses have been used widely in a range of surveys, examining a number of whelk species (Stroben et al. 1995).

In view of the toxicity of TBT it is not surprising that legislative control aimed at regulating the use of TBTbased antifouling paints has been introduced in a number of countries, of which France was the first in 1982. The French government believed small boats to be the main source of contamination in coastal waters, and prohibited the use of TBT on vessels $<25 \mathrm{~m}$ in length. Similar regulations followed, for example, in Britain and several other European countries, the USA, Canada, New Zealand and Australia (Stewart 1996), and proved to be highly effective in reducing TBT contamination. The ambient levels of butyltins decreased in the water column, sediment and the tissues of molluscs, and since then there has been a substantial recovery of the affected populations of oysters and whelks (see review by Evans et al. 1995). Centres of commercial shipping activity, especially harbours with dry docks, are still hotspots of contamination, but the impact is surprisingly local (Evans et al. 1996). However, other countries, including Israel, have not regulated the use of TBT-based antifoulants, and backyrumu hevels of contantination inay already be hight in their coastal waters. Moreover, it is feared that the situation will worsen with the current and planned development of yachting marinas at several coastal resorts in Israel. To date, there have been relatively few stucties of the effects of TBT in the Mediterranean Sea, but high concentrations have been reported in the
Tyrrhenian Sea, Italy (Bacci \& Gaggi 1989), Turkey and Egypt during the MEDPOL survey (Gabrielides et al. 1990), the Bay of Naples (Cocchieri et al. 1993) and the Côte d'Azur, France, even after the introduction of regulations (Tolosa et al. 1996). So far, the only evidence of imposex associated with TBT pollution in the Mediterranean comes from the coastal waters of Malta (Axiak et al. 1995), where severe symptoms were found in the whelk Hexaplex trunculus.

The overall objective of the present study was to assess current levels of butyltin contamination along the eastern Mediterranean coast of Israel. Particular attention was paid to 2 marinas - a well-established one in Tel Aviv (commenced operation 1974) and a recently constructed one in Herzelia (opened late 1995) - and to the extent to which contamination originating from harbouring yachts pollutes adjacent coastal areas. The degree of pollution was assessed according to the level of butyltins found in the tissues and the severity of imposex, in 2 local whelks, Stramonita haemastoma and Hexaplex trunculus. The accumulated data also enabled us to compare the biological responses of the 2 whelk species

\section{METHODS}

Field surveys. An initial survey of the Mediterranean coast of Israel, based on collections of Stramonita haemastoma, was carried out in several sites (Fig 1) during September and November 1996. Most populations are located in the infralittoral, and the whelks were therefore collected by SCUBA diving, with the exception of the mid-littoral population at Akhziv, which was collected by wading At each site 10 to 35 individuals were collected, according to population size. Habitat characteristics and proximity to areas of boating activity at each site were as follows: (1) Ashqelon, infralittoral boulders and bedrock, to depths of 2 to $3 \mathrm{~m}$ below datum, $2.5 \mathrm{~km}$ north of an oil jetty; (2) Palmachim, vertical walls of sandstone platforms 2 to $3 \mathrm{~m}$ deep, no boating activity; (3) Bat-Yam, walls of sandstone platforms 2 to $3 \mathrm{~m}$ deep, some activity of small boats from an adjacent maritime school; (4) Tel Aviv marina, a quarry-rock wave-breaker, $5 \mathrm{~m}$ deep, outside the marina entrance, ca 300 yachts (full capacity): (5) Herzelia marina, a concrete-tetrapod and quarryrock wave-breaker, $7 \mathrm{~m}$ deep, outside of the marina entrunce, ca 200 yachts (potential capucity of 900 ), (6) Mikhmoret, vertical walls of sandstone platforms, 2 to $3 \mathrm{~m}$ deep, small number of yachts at the Maritime School; (7) HaBonim, walls of sandstone platforms, 2 to $3 \mathrm{~m}$ deep, a nature reserve with no boating activity; (8) Akhziv, midlittoral rocks of incisioned-rock type, no boating activity. 


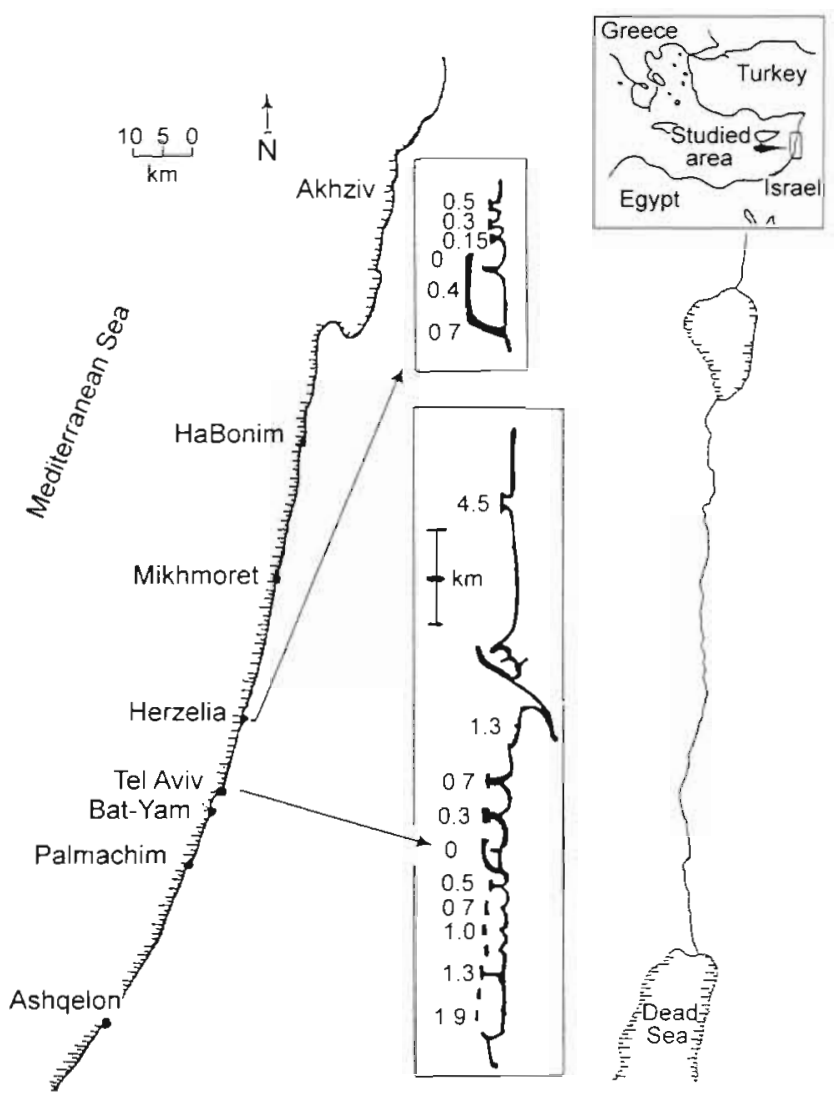

Fig. 1. Study area and sampling sites along the Israeli Mediterranean coast. Inserts include the Herzelia (top) and Tel Aviv (bottom) marinas; numbers represent distances in $\mathrm{km}$ from the marina entrance

The second survey included both Stramonita haemastoma and Hexaplex trunculus, and was carried out in March 1997 mostly by SCUBA diving. This survey included only the yachting marinas at Tel Aviv and Herzelia, and 2 reference sites, at Akhziv and HaBonim, distant from boating activity. Detailed surveys were made in areas adjacent to the 2 marinas, including the outer walls of the marinas and a series of wave breakers at increasing distances from them (Fig. 1). The breakers were about $50 \mathrm{~m}$ from the shore and parallel to it, separated from each other by a sandy bottom. We chose 5 sampling sites to the south of $\mathrm{Tel}$ Aviv marina entrance, at distances of $0.5,0.7,1.0,1.3$ and $1.9 \mathrm{~km}$ (bottom depth $5 \mathrm{~m}$ ), and 4 sampling sites to the north at distances of $0.3,0.7,1.3$ and $4.5 \mathrm{~km}$ (bottom depth $4 \mathrm{~m}$ ). We used 2 sampling sites south of Herzelia marina entrance outside the wave breaker at distances of 0.4 and $0.7 \mathrm{~km}$ (bottom depth $7 \mathrm{~m}$ ), and 3 to the north at distances of $0.15,0.3$ and $0.5 \mathrm{~km}$ (bottom depth $4 \mathrm{~m}$ ). Sample sizes ranged from 5 to 54 for $S$. haemastoma and from 2 to 50 ind. for $H$. trunculus, depending on abundance. Abundance for each species was expressed as number of whelks observed per unit effort (NUE), i.e. per minute of search time (adopted from McClanhan \& Muthiga 1992), which according to these authors is cost-effective and produces fairly reliable population estimates.

Measurement of imposex. RPSI only was assessed in the initial survey of Stramonita haemastoma (September to November 1996). The whelks were kept in wellaerated seawater for $1 \mathrm{wk}$ after collection. They were then anaesthetised (relaxed) in a solution of $5 \%$ magnesium chloride in seawater. Shell length was measured to the nearest $0.1 \mathrm{~mm}$ using vernier callipers. The shell was broken, either with a vice or hammer, and separated from the soft body. Sex was determined by presence or absence of the sperm-ingesting gland and the sex ratio was calculated (Spence et al. 1990). The length of the curved penis was measured to the nearest $0.1 \mathrm{~mm}$ using a binocular microscope fitted with an eyepiece graticule. RPSI was calculated as follows:

$$
\text { RPSI }=\frac{(\text { mean female penis length })^{3}}{(\text { mean male penis length })^{3}} \times 100
$$

Whelks collected in the second survey (March 1997) were transported to the laboratory and frozen to $-20^{\circ} \mathrm{C}$. In April 1997 they were air-shipped to the Dove Marine Laboratory (University of Newcastle, UK) for imposex analysis. The length of each shell was measured and it was then defrosted and the shell broken as described above. The mantle was cut and folded back to reveal the genitalia. Stramonita haemastoma was sexed as described above. Since in Hexaplex trunculus the sperm-ingesting gland is almost unnoticeable, sex was determined on the basis of the color of the gonads (yellow/orange in females and mustard/grey in males), and the presence of the capsule gland and genital pore. Individuals were determined as sub-adults when the gonads could not be distinguished from the digestive gland (body whorl uniform in color), while these organs were easily recognisable in adults (Spence et al. 1990). There were no juveniles in the samples of either species (see 'Results'). The penis was straightened before being measured. VDSI was determined using categories 1 to 6 given by Gibbs et al. (1987) and Fioroni et al. (1991), and were already used for the 2 species under study by Spence et al. (1990) and Axiak et al. (1995). Chi-square test was used to determine significant deviations from sex ratio of $1: 1$ for whelks grouped from all sites around Tel Aviv and for those from the Herzelia area.

Organotin analysis. Tissue samples of Stramonita haemastoma and Hexaplex trunculus were analysed for butyltins by Battelle Ocean Sciences (Duxbury Operations, Duxbury, MA, USA). Soft parts of specimens we had already examined for imposex were airshipped frozen on dry ice. The tissues were homogenised before analysis. Butyltins were extracted from 
the matrix in subsamples using hexane and the chelating agent tropolone. The extract was then cleaned through a Florinil gel liquid chromatography column. The butyltins, including TBT and its breakdown products dibutyltin (DBT) and monobutyltin (MBT), were quantified by gas chromatography with a flame photometric detector, and using a tin-specific photometric filter (Horiguchi et al. 1994), and expressed as Sn. The detection limit was $1.3 \mathrm{ng} \mathrm{g}^{-1}$ dry weight, and the limit of quantification was $5 \mathrm{ng} \mathrm{g}^{-1}$ dry weight. Concentrations between these 2 limits were regarded only as traces. Differences in TBT, DBT MBT and total organotin (TOT) levels between the 2 whelk species were tested for significance using the Wilcoxon signed-ranks test for 2 groups arranged as paired observations $(n=16)$.

\section{RESULTS}

\section{Imposex and TBT contamination along the Israeli coast}

Imposex was evident in all the samples of Stramonita haemastoma and Hexaplex trunculus including those from the 2 reference sites at HaBonim and Akhziv (Table 1). There were nevertheless considerable differences in the severity of the symptoms recorded at the different sites. Imposex was most advanced in samples collected from the marinas at Tel Aviv and Herzelia and. though to a lesser extent, Ashqelon. All females examined from the 2 marinas and most from Ashqelon displayed imposex (had a penis), and their penises were well-developed with RPSI $>9 \%$. An increase in RPSI value in $S$. haemastoma was found in the Herzelia marina entrance from November 1996 (22\%) to March 1997 (36\%), while no such increase was evident in the old Tel Aviv marina. Imposex was relatively moderate (RPSI $<2 \%$ ) in samples from Palmachim, Bat Yam, Mikhmoret, HaBonim and Akhoiv, but most females there had developed a rudimentary penis. The only exception was HaBonim, where only $25 \%$ of the females demonstrated imposex. None of the sex ratios proved to be significant in a chi-square analysis (probably due to the small sample size), how-

Table 1 Imposex in samples of Stramonita haemastoma obtained during November 1996 in different locations from south to north along the Israeli Mediterranean coast

\begin{tabular}{|c|c|c|c|c|c|c|}
\hline \multirow[t]{2}{*}{ Location } & \multirow[t]{2}{*}{$\begin{array}{l}\text { Sample } \\
\text { size }\end{array}$} & \multirow{2}{*}{$\begin{array}{c}\text { Sex } \\
\text { ratio } \\
\mathrm{m} / \mathrm{f}\end{array}$} & \multicolumn{2}{|c|}{$\begin{array}{l}\text { Penis length } \\
\text { in } \mathrm{mm}( \pm \mathrm{SD})\end{array}$} & \multirow[t]{2}{*}{$\begin{array}{c}\text { Imposex } \\
(\%)\end{array}$} & \multirow[t]{2}{*}{$\begin{array}{c}\text { RPSI } \\
(\%)\end{array}$} \\
\hline & & & Female & Male & & \\
\hline Ashqelon & 20 & 1.2 & $4.8 \pm 2.7$ & $10.6 \pm 1.5$ & 88 & 9.2 \\
\hline Palmachim & 25 & 1.3 & $2.5 \pm 1.7$ & $13.1 \pm 2.6$ & 100 & 0.7 \\
\hline Bat-Yam & 26 & 1.2 & $1.2 \pm 1.3$ & $8.3+1.9$ & 66 & 0.3 \\
\hline Tel Aviv marina & 35 & 1.2 & $7.3 \pm 1.0$ & $7.6 \pm 1.1$ & 100 & 89.4 \\
\hline Herzelia marina & 30 & 1.1 & $5.0 \pm 1.1$ & $8.3 \pm 2.4$ & 100 & 22.0 \\
\hline Mikhmoret & 15 & 1.5 & $0.5 \pm 0.5$ & $5.4 \pm 1.5$ & 67 & 0.1 \\
\hline HaBonim & 10 & 1.5 & $0.6 \pm 1.2$ & $6.0 \pm 1.4$ & 25 & 0.1 \\
\hline Akhziv & 30 & 0.8 & $2.4 \pm 0.9$ & $10.3 \pm 1.5$ & 100 & 1.2 \\
\hline
\end{tabular}

ever males were more abundant than females in 7 out of the 8 sites $(F=5.06, \mathrm{p}<0.05)$.

Concentration of butyltins in tissues of both Stramonita haemastoma and Hexaplex trunculus were particularly high from the Tel Aviv and Herzelia marinas; TOTs were $>1000 \mathrm{ng} \mathrm{g}^{-1}$ dry weight in each case (Table 2). There were much lower, but nevertheless detectable, levels of butyltin in samples from HaBonim and Akhziv. DBT consisted ca 50 to $70 \%$ of all butyltin species in most of the samples, while TBT was only $16 \%$ in Tel Aviv marina and 30 to $45 \%$ in Herzelia (Table 2).

Tel Aviv
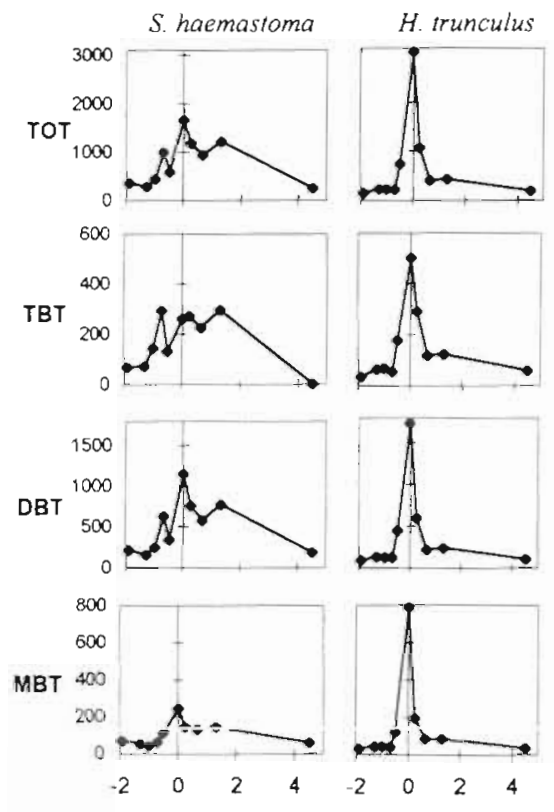

Distance from the marina entrance $(\mathrm{km})$

Fig. 2. Stramonita haemastoma and Hexaplex trunculus. Levels in $\mathrm{ng} \mathrm{g}^{-1} \mathrm{dry}$ tissue of TBT, its breakdown products, DBT and MBT, and total organotins (TOT), around the Tel Aviv and Herzelia marinas 


\section{Gradients of contamination from Tel Aviv and Herzelia marinas}

There were marked gradients of TBT contamination and its degraded forms, DBT and MBT, along with symptoms of imposex, which decreased progressively from both the old Tel Aviv marina and the newly constructed one at Herzelia (Figs. 2 \& 3); however, symptoms of imposex were more advanced in Tel Aviv than in Herzelia. There was a decrease in butyltin contamination at increasing distances from the 2 marinas. The highest concentrations of butyltin were recorded in samples collected from the marinas themselves, or immediately adjacent to them (Fig. 2), decreasing progressively at sites south- or northward. Concentrations were roughly 1 order of magnitude lower at distances $>1$ to $4 \mathrm{~km}$ from Tel Aviv and $>0.4 \mathrm{~km}$ from Herzelia marinas compared with the marina entrances. TBT comprised 14 to $45 \%(25.7 \pm 6.3 \%$, $\mathrm{n}=32$ ) of the TOT in both whelks around the 2 marinas (Fig. 2). The degraded form DBT has the highest value of the 3 butyltin forms (Fig. 2).

RPSI were high at the marinas and/or at adjacent sites, but were roughly 1 order of magnitude lower $>1$ to $2 \mathrm{~km}$ from Tel Aviv and $>0.3 \mathrm{~km}$ from Herzelia (Fig. 3). VDSI was high at all sites and there was evidence of a similar decrease with distance from the marina at Tel Aviv only. This trend is even more evident from Tel Aviv, if only sterile females are consid-
Tel Aviv
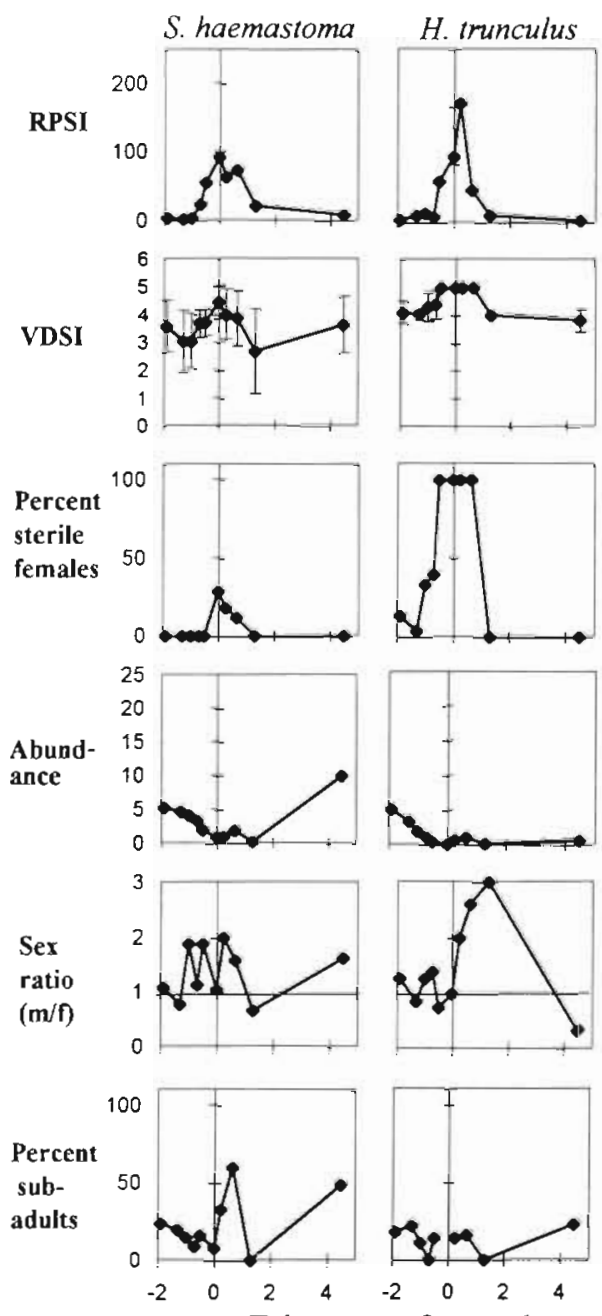

Distance from the marina entrance $(\mathrm{km})$

Fig. 3. Stramonita haemastoma and Hexaplex trunculus. Imposex indices, RPSI and VDSI, snail abundance in number per unit effort (NUE) and present sub-adults around the Tel Aviv and Herzelia marinas

ered, particularly of Hexaplex trunculus. All females at 4 sites adjacent to this marina were sterile, but the number of sterile females decreased at greater distances (Fig. 3).

Table 2. Organotin levels (ng $\mathrm{g}^{-1} \mathrm{dry}$ weight), including TBT, DBT and MBT, in Stramonita haemastoma and Hexaplex trunculus from the marina entrances and the 2 reference sites. Percent of TBT, DBT and MBT from TOT is given in parentheses. TOT: total organotins; nd: not detected

\begin{tabular}{|lcccccccc|}
\hline Site & \multicolumn{3}{c}{ Stramonita haemastoma } & & \multicolumn{2}{c}{ Hexaplex trunculus } \\
& TBT & DBT & MBT & TOT & TBT & DBT & MBT & TOT \\
\hline Tel Aviv marina entrance & $258.9(16)$ & $1142.4(70)$ & $239.6(14)$ & 1640.9 & $499.3(16)$ & $1732.3(57)$ & $786.1(27)$ & 3017.7 \\
Herzelia marina entrance & $447.7(30)$ & $913.6(61)$ & $111.3(9)$ & 1502.6 & $581.1(45)$ & $616.8(49)$ & $70.6(6)$ & 1268.5 \\
& & & & & & & & \\
HaBonim & $18.9(23)$ & $51.2(62)$ & $12.2(15)$ & 82.3 & $38.1(40)$ & $36.5(38)$ & $20.3(22)$ & 94.9 \\
Akhziv & nd & $22.7(70)$ & $9.9(30)$ & 32.6 & $18.7(49)$ & $19.8(51)$ & nd & 38.5 \\
\hline
\end{tabular}


Tissue concentrations of organotins in both species significantly correlated ( $p<0.001$ ) with the severity of the imposex symptoms, measured as RPSI or VDSI (Fig. 4). TBT, MBT, DBT and TOT concentrations were significantly higher in Stramonita haemastoma than in Hexaplex trunculus in 12 to 14 of the 16 sites around the marinas $\left(T_{16}=32\right.$, $p<0.05 ; T_{16}=19, p<0.005 ; T_{16}=28, p<$ 0.05 and $T_{16}=20, p<0.01$, respectively; Wilcoxon's signed-ranks test). One case in which $H$. trunculus had higher levels was at the Tel Aviv marina entrance (Fig. 2), but the measurement here was based only on 2 large individuals (Table 2).

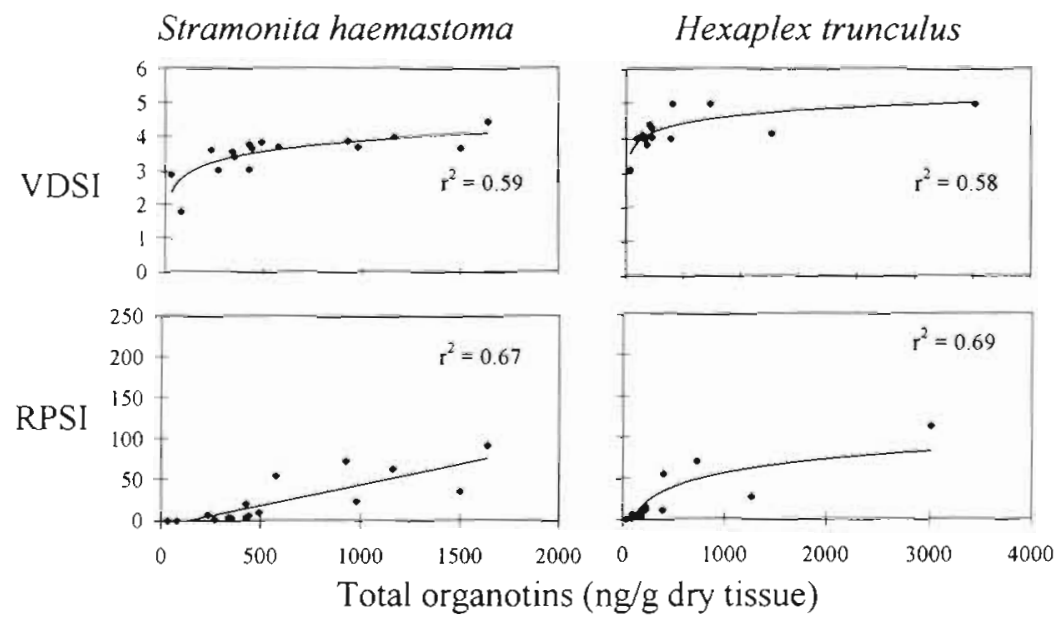

Fig. 4. Stramonita haemastoma and Hexaplex trunculus. Relationship between imposex indices, RPSI and VDSI, and levels of total organotins

\section{The impact of TBT contamination adjacent to marinas}

Stramonita haemastoma and Hexaplex trunculus were found at low densities at the Tel Aviv and Herzelia marinas. In the case of $S$. haemastoma, numbers tended to increase at sampling sites at progressively increasing distances south-and northward (Fig. 3). The same trend was evident in the abundance of $H$. trunculus with increasing distance to the south of the 2 marinas, but not to the north. There was a negative correlation between the abundance of $S$. haemastoma and TOTs in tissue samples $\left(r^{2}=-0.69, p<0.05\right)$, while in $H$. trunculus it was not significant $\left(r^{2}=-0.28, p>0.05\right)$.

There was no evidence of recent recruitment of juveniles into populations at any of the sites. In Tel Aviv $4.7 \%$ (20 of 408 whelks) of Stramonita haemastoma collected were $<50 \mathrm{~mm}$ in shell length, and $21 \%$ (42 of 200 whelks) of Hexaplex trunculus were $<40 \mathrm{~mm}$. In Herzelia $22 \%$ (87 of 403 whelks) of the S. haemastoma collected were $<50 \mathrm{~mm}$ and $26 \%$ (77 of 297 whelks) of the $H$. trunculus were $<40 \mathrm{~mm}$. Some sub-adults were tound, however, indicating that recruitment may have occurred at some time in the recent past, mainly in Herzelia (Fig. 3). Nevertheless, their numbers varied considerably among sites and there appears to be no relationship between them and either levels of butyltin contamination or the severity of imposex (Figs. $2 \& 3$ ). Although sex ratio of $S$. haemastoma fluctuated around the Tol Aviv marina, there were more males than females at most sites (Fig. 3). The pooled data were significantly biased towards males in this area (241 and 178 respectively, $F=9.5, p<0.005$, while no significant difference in gender numbers was found in either the Herzelia area (112 and 94) or in H. trunculus from Tel Aviv (149 and 154) or Herzelia (135 and 119).
TBT contamination may have affected the size of male and female whelks. Females of Hexaplex trunculus were significantly larger than males at the polluted sites of Tel Aviv and Herzelia (means differ by 7.3 and $7.5 \mathrm{~mm}$ respectively). Females of Stramonita haemastoma were significantly larger than males at Tel Aviv (means differ by only $1.5 \mathrm{~mm}$ ), while there were no significant differences in the sizes of the 2 sexes from the reference sites at HaBonim and Akhziv (Table 3). Mean shell length positively correlated with levels of TOT in $H$. trunculus (Fig. 5a), while no such correlation was evident in S. haemastoma (Fig 5b).

\section{DISCUSSION}

\section{TBT contamination}

Our study presents the first evidence of imposex in the eastern Mediterranean, in general, and TBT pollu-

Table 3. Mean shell length $( \pm S D)$ of maje and female Stramonita haemastoma and Hexaplex trunculus from the 2 marinas and 'reference' sites. Differences between mean sizes of males and females were tested using 1-way ANOVA. ns: not significant

\begin{tabular}{|c|c|c|c|c|}
\hline & Tel Aviv & Herzelia & HaBonim & Akhziv \\
\hline \multicolumn{5}{|c|}{ S. haemastoma } \\
\hline Males & $57.6 \pm 5.3$ & $55.7: \pm 8.2$ & $46.1 \pm 3.6$ & $63.2 \pm 5.2$ \\
\hline remales & $5 y .1 \pm 0.3$ & $36.1 \pm 8.3$ & $4.5 .8 \pm 4.4$ & $b 2.8 \pm 0.1$ \\
\hline $\mathrm{p}$ & 0.005 & ns & ns & ns \\
\hline \multicolumn{5}{|c|}{ H. trunculus } \\
\hline Males & $41.6 \pm 6.7$ & $40.1 \pm 7.2$ & $41.8 \pm 8.8$ & $39.1 \pm 7.3$ \\
\hline Females & $48.9 \pm 5.9$ & $47.6 \pm 6.9$ & 49.2 & $42.6 \pm 7.7$ \\
\hline $\mathrm{p}$ & 0.0001 & 0.0001 & ns & ns \\
\hline
\end{tabular}




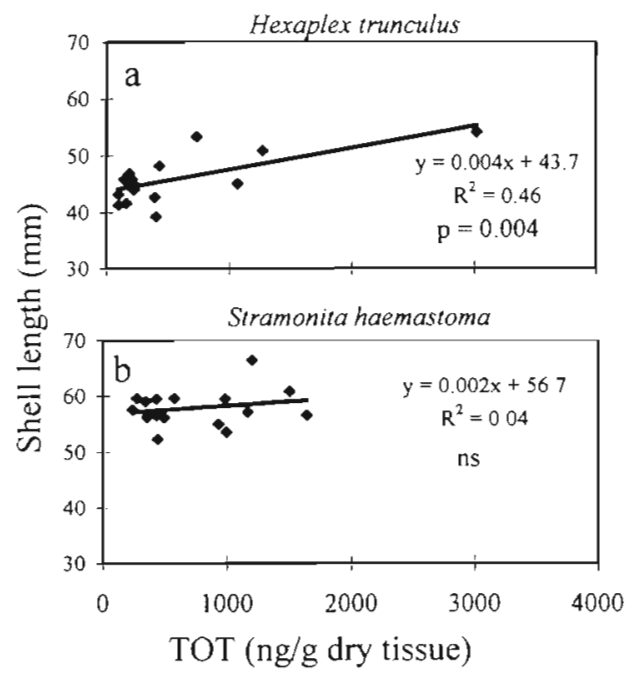

Fig. 5. Stramonita haemastoma and Hexaplex trunculus. Relationship between total organotin (TOT) concentration and shell length

tion in Israel, in particular. TBT contamination in the coastal waters of Israel is high and at least as bad as that described elsewhere where the use of TBT-based paints is unregulated. Butyltin concentrations (>1000 ng $\mathrm{g}^{-1}$ ) in the tissues of the whelks Stramonita haemastoma and Hexaplex trunculus from the marinas at Tel Aviv and Herzelia are generally higher than those recorded in $H$. trunculus from marina and harbour sites in Malta (Axiak et al. 1995). Similarly, imposex in our samples of $S$. haemastoma was as well-developed or even more pronounced than that described in the same species from marinas in the Azores (Spence et al. 1990) and commercial harbours in Ghana (Nyarko \& Evans 1997). Imposex in $H$. trunculus from Israel was shown to be as severe or higher than in the same species from Malta (Axiak et al. 1995). The situation in these 2 Mediterranean countries is in marked contrast to where regulations limiting the use of TBT-based antifoulants to vessels $<25 \mathrm{~m}$ in length are in force. Where such regulations have been implemented, concentrations of butyltins have declined in the water column, sediment and tissues of molluscs, symptoms of imposex have decreased, and there has been recovery of affected populations of the dogwhelk Nucella lapillus and the oyster Crassostrea gigas (for review see Evans et al. 1995).

Marinas are major hotspots of TBT contamination along the coast of Israel, with a marked decrease in pollution at distances of $<1$ to $2 \mathrm{~km}$ from them (Fig. 2), presumably due to dilution effects by the open seas. Similar localised impact of TBT from centres of boating or mariculture activity has been reported in several studies, such as in the Scottish sea lochs (Davies et al.
1987), Sullom Voe (Bailey \& Davies 1988), Porirua Inlet and Wellington Harbour, New Zealand (Smith \& McVeagh 1991), Port Philip Bay, Australia (Foale 1993) and Indonesia (Evans et al. 1995. Pandey \& Evans 1996). In the present study, however, butyltin levels were still observed to be relatively high $5 \mathrm{~km}$ to the north of the Tel Aviv marina (ca $200 \mathrm{ng} \mathrm{g}^{-1}$ dry tissue), and even detected at the reference sites at Akhziv and HaBonim, where they were sufficiently high to cause imposex in the whelks. The higher TBT/TOT ratio in contaminated sites in Israel $(25.7 \pm 6.3 \%)$ as compared to those in Malta $(9.7 \pm 6.3 \%$, recalculated from Axiak et al. 1995), and in the Herzelia versus the Tel Aviv marina, may be related to the degree of freshness of contaminant inputs (Tolosa et al. 1996, Ruiz et al. 1998).

The study of the Herzelia marina offered a unique opportunity to witness in the field the rapid and intense response of whelks to TBT pollution around a newly constructed source of contamination in an open coastline. Since dilution is probably very intense on such an open coast it is quite surprising that TBT levels, and consequently imposex intensity, reached high values in just 1.5 yr since the marina was opened. We have evidence of a rapid development of imposex in 3 whelk species near another newly established marina located in the south of Israel (Ashqelon, Fig. 1), which was opened late in 1995. Already in November 1997 RPSI and VDSI values, respectively, were as follows: in Stramonita haemastoma 32.7 and $4 \%$; in Hexaplex trunculus 8.7 and $3.7 \%$; and in the Red Sea emigrant whelk Thais carinifera 19.4 and $3.5 \%$ (unpubl. data). This very rapid imposex response indicates high TBT accumulation rates near this newly established marina. Such results are a cause for alarm and undoubtedly demonstrate a need for further study.

\section{Biological impact}

The biological impact of TBT contamination was most severe at the Tel Aviv and Herzelia marinas. All Hexaplex trunculus females collected within ca $1 \mathrm{~km}$ of Tel Aviv marina were sterile, and the species was rare within this range. This whelk displays direct development (Spight 1977), and recruitment can therefore not take place as a result of the dispersal of larvae from fecund populations elsewhere. Despite the presence of a few sub-adults, which indicates some recent recruitment, the populations close to these marinas can be expected to die out in the near future. Local extinction of Nucella lapillus, which has a similar life history to $H$. trunculus, has already occurred in several areas of high boating activity in Europe (Bryan et al. 1986, Evans et al. 1996). Most females of Stra- 
monita haemastoma examined in the current study were fertile, including $70 \%$ at the Tel Aviv marina (Fig. 3). S. haemastoma was also more abundant than $H$. trunculus at the 2 marina sites. The indirect development of this species (Spight 1977, Butler 1985) offers a potential supply of recruits from fecund populations to polluted areas and is therefore unlikely to suffer from local extinction due to TBT contamination. Such appears to be the case in Hong Kong and Singapore, where Thais spp. is abundant in many areas of high shipping activity, despite TBT pollution being high and all females being sterile (Evans et al. unpubl.). Our finding of a pronounced reduction in abundance of both studied species near the marinas (Fig. 3 ) is thus surprising, and might result from a greater mortality of larvae as they approach the highly contaminated area, or of small juveniles after settlement. This assumption appears to be supported by evidence showing that larvae and spats of bivalves are susceptible to TBT, suffering from high mortality rates and low shell growth when exposed to the contaminant (Lapota et al. 1993, Ruiz et al. 1994, 1995a, b).

The absence of juvenile stages of either Stramonita haemastoma or Hexaplex trunculus in any of the samples collected in the present study is surprising in view of their presence in samples of $S$. haemastoma in Louisiana (Brown \& Richardson 1987), the Azores (Spence et al. 1990) and Ghana (Nyarko \& Evans 1997). This may be related to a general reduction in reproduction and/or larval survival, resulting in low recruitment rates in the area. Rilov et al. (unpubl.) has suggested that recent environmental changes such as alteration in salinity and the appearance of a new invasive medusa, together with TBT pollution, might have contributed to the recent reduction in recruitment of S. haemastoma. Lack of juveniles may also be due to erratic breeding (see Brown \& Richardson 1987), although there is evidence that recruitment has rarely occurred among the populations examined for the last. 4 yr along the Israeli coastline (Rilov et al. unpubl.). If this is attributable to breeding failure, it is unlikely to be related solely to TBT pollution because it also applies to populations of whelks from relatively clean sites, such as HaBonim and Akhziv, as well as from severely contaminated ones.

In the present study we found evidence that TBT contamination affected the size of Stramonita haemastoma and Hexaplex trunculus (Table 3). Females of both species were significantly larger than mates nnly around the contaminated sites in Tel Aviv, and in the latter species also in Herzelia. Larger females were also found among $H$. trunculus from Malta, albett in both contaminated and clean areas (Axiak et al. 1995). It is possible that in this species size difference between sexes is a natural phenomenon which is accen- tuated by TBT contamination, while in S. haemastoma it results only from high pollution levels. Gorbushin (1997) has described a similar impact on growth in the snail Hydrobia ulva as a result of infestation by larval trematodes. Heavily parasitised snails grew larger but had poorly developed gonads, and the author suggested that this was the result of an energy reallocation from reproduction to somatic growth. Axiak et al. (1995) proposed a similar explanation for the increased mean size in $H$. trunculus in highly contaminated areas. Similarly, we found a positive correlation between organotin levels and mean size in this species. It is therefore possible that in our study females of both species were larger as a result of higher somatic growth due to lower reproductive capability, and that the phenomenon is more pronounced in $H$. trunculus. This hypothesis requires manipulative studies of TBT exposure for verification. The possibility that differences in habitat condition other then TBT levels (e.g. food availability) can affect different whelk growth should not be excluded.

In addition to the degree of size difference between sexes and the expression of imposex in sterile females, i.e. occlusion of the vagina in Stramonita haemastoma versus a split in the capsule gland in Hexaplex trunculus (see 'Methods'), we found 2 other, presumably TBT-related differences between the species. The first was a shift in sex ratio from $1: 1$ which was evident only in $S$. haemastoma around the old marina in Tel Aviv, where populations generally had more males (see 'Results'). A similar phenomenon was found by others (e.g. Bryan et al. 1986, Bright \& Ellis 1989, Nias et al. 1993, Nicholson \& Evans 1997) and was related to severe imposex killing females. Such a shift was also evident in Thais clavigera from Taiwan (Liu \& Chen 1992), though imposex was not examined there. However, in our study male dominance seemed to exist in most places where imposex symptoms were relatively low and no sterile females were found. It is therefore suggested that, if slight male domination is not a natural phenomenon in S. haemastoma, high TBT contamination led to greater female mortality through an as yet unknown mechanism. Alternatively, it is possible that some females went through a complete sex change, as was evident in some neogastropod species exposed to TBT contamination (Gibbs et al. 1988, 1990, Oehlmann et al. 1996) The second difference between species was the significantly higher butyltin accumulation in $S$ hasmastomathan in $H$ trunculus. Such dif. ferences in butytin levels among co-occurring species were noticed by Oehlmann et al. (1996), who also correlated them to differences in the imposex indices and interpreted them as different TBT-sensitivity of the species. Stroben et al. (1992), however, found no difference in TBT accumulation in exposure experiments 
with Ninia reticulata and Nucella lapillus. Alternatively, such differences may be related to differential accumulation and/or detoxification rates between species, or to a dietary difference, since some of the TBT may have been accumulated through the food chain (Stickle 1990).

\section{Conclusions}

The results of our study suggest that the newly constructed marinas and the proposed development of additional ones along the Israeli coastline could have severe environmental consequences, Moreover, since the coastline is short-only $190 \mathrm{~km}$ - the proposed construction of 10 more marinas will produce a series of contamination sources which, in turn, will increase TBT levels considerably. The main concern is that, although such serious biological impact as breeding impairment or failure caused by TBT appears to be limited to the areas immediately adjacent to marinas, butyltin contamination is already evident at sites remote from major shipping activity. It should be noted that nearshore shipping may have also contributed to the TBT contamination at these more distant sites (Ruiz et al. 1998). Furthermore, we have evidence that the situation is already worsening: the Herzelia marina has the capacity to take up to 800 yachts, 4 times more than at present, and ambient levels of TBT are already similar to those at the old marina in Tel Aviv. In addition, measures of imposex RPSI at Herzelia increased from 22 to $36 \%$ within a 5 mo period (November 1996 to March 1997), a finding which may imply that pollution levels have increased and that the consequent biological response (imposex) developed rapidly. Further monitoring is required to confirm this finding.

The predicted elevation of TBT levels along the Israeli coastline should certainly be avoided because, despite the surprisingly sparse information on the impact of TBT pollution on ecosystems, it is unquestionably known to be toxic to a wide range of marine organisms, including microalgae (Beaumont \& Newman 1986), polychaetes and bivalves (Beaumont et al. 1989), crustaceans (Rexrode 1987), fish (Wester et al. 1990) and coelenterates (Mercier et al. 1996). Regulations limiting the use of TBT-based antifloulants have been successful in reducing TBT contamination in Europe (Evans et al. 1995). It is therefore recommended that regulations either limiting or, once a proven safe alternative is available, banning the use of TBT-based antifoulants should be introduced in Israel. Further development of marinas should certainly not be contemplated until such regulations are in place.
Acknowledgements. We are grateful to the staff of the Dove Marine Laboratory for the kind hospitality and assistance. Special thanks to Camila, Valia and Rhian for the hours they spent anatomically analysing the snails. We also thank the Nature Reserves Authority for the permit to work in the nature reserves along the Israeli Mediterranean coast. N. Paz is acknowledged for editorial assistance. We are grateful to the British Council for grant in aid which allowed the visit of G.R. to the Dove Marine Laboratory. We would also like to thank Dr Ulrich Stewen of Witco and Dr Jan Jonker of Elf-Atochem for financial support. This research was also supported in part by a grant from the Israeli Ministry of the Environment.

\section{LITERATURE CITED}

Axiak V, Vella AJ, Micallef D, Chircop P, Mintoff B (1995) Imposex in Hexaplex trunculus (Gastropoda: Muricidae): first results from biomonitoring of tributyltin contamination in the Mediterranean. Mar Biol 121:685-691

Bacci E, Gaggi C (1989) Organotin compounds in harbour and marine waters from the northern Tyrrhenian Sea. Mar PolIut Bull 20:290-292

Bailey SK, Davies IM (1988) Tributyltin contamination around an oil terminal in Sullom Voe (Scotland). Environ Pollut 55: $161-172$

Beaumont AR, Newman PB (1986) Low levels of tributyltin reduce growth of marine micro-algae. Mar Pollut Bull 17. $457-461$

Beaumont AR, Newman PB, Mills DK, Waldock MJ, Miller D, Waite ME (1989) Sandy-substrate microcosm studies on tributyltin (TBT) toxicity to marine organisms. Sci Mar 53: $737-743$

Bright DA, Ellis DV (1990) A comparative survey of imposex in Northeast Pacific neogastropods (Prosobranchia) related to tributyltin contamination, and choice of a suitable bioindicator. Can J Zool 68:1915-1924

Brown KM, Richardson TD (1987) Foraging ecology of the southern oyster drill Thais haemastoma (Grey): constraints on prey choice. J Exp Mar Biol Ecol 114:123-141

Bryan GW, Gibbs PE, Huggett RJ, Hummerstone LG, Burt GR (1986) The decline of the gastropod Nucella lapillus around south-west England: evidence for the effect of tributyltin form antifouling paints. J Mar Biol Assoc UK 66: $611-640$

Butler PA (1985) Synoptic review of the literature on the Southern Oyster Drill Thais haemastoma floridana. NOAA Tech Rep NMFS 35:1-9

Claisse D, Alzieu C (1993) Copper contamination as a result of antifouling paint regulation? Mar Pollut Bull 26: 395-39?

Davies IM, Bailey SK, Moore DC (1987) Tributyltin in Scottish sea lochs, as indicated by degree of imposex in the dogwhelk, Nucella lapillus (L.). Mar Pollut Bull 18:400-404

Dyryanda EA (1992) Incidence of abnormal shell thickening in the Pacific oyster Crassostrea gigas in Poole Harbour (UK), subsequent to the 1987 TBT restrictions. Mar Pollut. Bull 24:156-163

Evans SM, Leksoma T, McKinnell PD (1995) Tributyltin pollution: a diminishing problem following legislation limiting the use of TBT-based antifouling paints. Mar Pollut Bull 30:14-21

Evans SM, Evans PM, Leksono T (1996) Widespread recovery of dogwhelks, Nucella lapillus (L.), from tributyltin contamination in the North Sea with Clyde Sea. Mar Pollut Bull $32: 263-269$ 
Fioroni P, Oehlmann J, Stroben E (1991) The pseudohermaphroditism of prosobranchs: morphological aspects Zool Anz 226:1-26

Foale S (1993) An evaluation of the potential of gastropod imposex as a bioindicator of tributyltin pollution in Port Philip Bay, Victoria. Mar Pollut Bull 26:546-552

Gabrielides GP, Alzieu C, Readman JW, Bacci E, Aboul Dahab O, Salihoglu 1 (1990) MED POL survey of organotins in the Mediterranean. Mar Pollut Bull 21:233-237

Gibbs PE, Pascoe PL, Burt GR (1987) The use of the dogwhelk (Nucella Lapillus) as and indicator of TBT contamination. J Mar Biol Assoc UK 67:502-524

Gibbs PE, Bryan GW, Pascoe PL, Burt GR (1988) Sex change in the female dogwhelk. Nucella Lapillus, induced by tributyltin from antifouling paints. J Mar Biol Assoc UK 68: 715-731

Gibbs PE, Bryan GW, Pascoe PL, Burt GR (1990) Reproductive abnormalties in female Ocenebra erinacea (Gastropoda) resulting from tributyltin-induced imposex. J Mar Biol Assoc UK 70:639-656

Goldberg ED (1986) TBT an environmental dilemma. Environment $28: 17-44$

Gorbushin AM (1997) Field evidence of trematod-induced gigantism in Hydrobia spp. (Gastropoda: Prosobranchia) J Mar Biol Assoc UK 77:785-800

Horiguchi T, Shiraishi H. Shimizu M, Morita M (1994) Imposex and organotin compounds in Thais clavigera and $T$ bronni in Japan. J Mar Biol Assoc UK 74:651-699

Lapota D, Rosenberger DE, Platter-Rieger MF, Seligman PF (1993) Growth and survival of Mytilus edulis larvae exposed to low levels of dibutyltin and tributyltin. Mar Biol $115: 431-419$

Liu L, Chen J (1992) Sex ratio changes of the oyster dnll Thais clavigera Kuster in Taıwan. J Fish Soc Taiwan 19 $85-88$

McClanahan TR, Muthiga NA. (1992) Comparative samping methods for subtidal epibenthic gastropods. J Exp Mar Biol Ecol 164:87-101

Mercier A. Pelletier E, Hamel JF (1996) Effects of butyltins on the symbiotic sea anemone Alptazia pallida (Veerrill) J Exp Mar Biol Ecol 215 (2):289-304

Nias DJ, McKillup SC, Edyvane KS (1993) Imposex in Lepsiella vinosa from southern Australia. Mar Pollut Bull 26: 380-384

Nicholson G $J_{r}$ Evans SM (1997) Anthropogenic impacts on the stocks of the common whelk Buccinum undatum (L.) Mar Environ Res 44:305-314

Nyarko E, Evans SM (1997) Impacts of tributyltin pollution and human food gathering on population of the gastropods Thais haemastoma and Thais nodosa along the Ghana coast. In: Evans SM Vaderpuye CJ. Armah (eds) The coastal zone of West Africa: problems and management. Penshaw Press, Sutherland, p 93-101

Oehlmann J, Stroben E, Fioroni P (1991) The morphological expression of imposex in Nucella lapillus (Linnaeus) (Gastropoda: Muricidae). J Molluscan Stud 57:375-390

Editorial responsibility: William Stickle (Contributing Editor), Baton Rouge, Louisiana, USA.
Oehlmann J, Fioroni P, Stroben E, Market B (1996) Tributyltin (TBT) effects on Ocinebrina aciculata (Gastropoda: Muricidae): imposex development, sterilisation, sex change and population decline. Sci Total Env 188:205-233

Pandey E, Evans SM (1996) The incidence of imposex in gasrropods from Indonesian coastal waters. Asian Mar Biol 13:53-61

Rexrode M (1987) Ecotoxicity of tributyltin. Proc Organotin Symp Oceans ' 87 Conf, Halifax, NS 4:1443-1455

Ruiz JM, Bryan GW, Gibbs PE (1994) Chronic toxicity of water tributyltin (TBT) and copper to spat of the bivalve Scrobicularia plana: ecological implications. Mat Ecol Prog Ser 113:105-117

Ruiz JM, Bryan GW, Gibbs PE (1995a) Acute and chronic toxicity of tributyltin (TBT) to pediveliger larvae of the bivalve Scrobicularia plana. Mar Biol 124:119-126

Ruiz JM, Bryan GW, Gibbs PE (1995b) Effects of tributyltin (TBT) exposure on the veliger larval development of the bivalve Scrobicularia plana (da Costa). J Exp Mar Biol Ecol 186:53-63

Ruiz JM, Quintela M, Barreiro R (1998) Ubiquitous imposex and organotin bioaccumulation in gastropods Nucella lapillus from Galicia (NW Spain): a possible effect of nearshore shipping. Mar Ecol Prog Ser 164:237-244

Smith PJ, McVeagh M (1991) Widespread organotin pollution in New Zealand coastal waters as indicated by imposex in dog whelks. Mar Pollut Bull 22(8):409-413

Spence SK, Hawkins SJ, Santos RS (1990) The mollusc Thais haemastoma-an exhibitor of 'imposex' and potential brological indicator of Tributyltin pollution. PSZN I: Mar Ecol 11:147-156

Spight TM (1977) Latitude, habitat, and hatching type for muricacean gastropods. Nautilus 91:67.71

Stewart C (1996) The efficacy of legislation in controlling tributyltin in the marine environment. In: de Mora SJ (ed) Tributyltin: case study of an envronmental contaminant Cambridge University Press, Cambridge, p 264-297

Stickle WB, Sharp-Dahl JL, Rice SD, Short JW (1990) Imposex induction in Nucella lima (Gmelin) via mode of exposure to tributyltin. J Exp Mar Biol Ecol 143:165-180

Stroben E, Oehlmann J, Froroni P (1992) Hinia reticulata and Nucella lapillus. Comparison of two gastropod tributyltin biondicators. Mar Biol 114:289-296

Stroben E, Schulte-Oehlmann U, Fioroni P, Oehlmann J (1995) A comparative method of easy assessment of coastal TBT pollution by the degree of imposex in prosobranch species. Haliotis 24:1-12

Tolosa I, Readman JW, Blaevoet A, Ghilin S, Bartocc J, Horvat M (1996) Contamination of Mediterranean (Cote d'Azuri coastal waters by organotins and Irgarol 1051 used in antifouling paints. Mar Pollut Bull 32:335-341

Wester PW, Canton JH, Van-Tersel AAJ, Kranjnc EI, Vaessen HAMG (1990) The toxicity of bis (tri-n-butyltin) oxide (TBTO) and di-n-butyltin dichloride (DBTC) in the small fish species Oryzias latipes (medaka) and Poecilia retıculata (guppy). Aquat Toxicol (Amst) 16:53-72

Submilted: November 10, 1998; Accepted: August 23, 1999 Proots received from author(s). January 24, 2000 